\title{
A SZOLGÁLTATÓ ROBOTOK DEFINIÁLÁSA ÉS ALKALMAZÁSI LEHETŐSÉGEI AZ ÜZLETI SZERVEZETEKBEN - SZISZTEMATIKUS IRODALMI ÁTTEKINTÉS
}

\author{
DEFINITION AND APPLICATION POSSIBILITIES OF SERVICE ROBOTS \\ IN BUSINESS ORGANIZATIONS - A SYSTEMATIC LITERATURE \\ REVIEW
}

A szolgáltató robotok egyre szofisztikáltabb feladatokat képesek ellátni mind a fizikai, mind a kognitív tevékenységek tekintetében. Az irántuk való kereslet világszinten növekszik, amit jól alátámasztanak azok az előrejelzések is, melyek alapján 2025-re a fogyasztói interakciók 85 százaléka emberi alkalmazott nélkül fog zajlani. A szolgáltató robotok bevezetése tehát egyre elterjedtebbé válik a különböző iparágakban. Jelen cikk célja a szolgáltató robotok definiálása és alkalmazási lehetőségeik áttekintése, melyhez szisztematikus irodalomkutatást végeztek a szerzők. A cikkben a bevezetést követően bemutatják az irodalomkutatás módszerét, majd meghatározzák a szolgáltató robotok fogalmát az áttekintett irodalomban fellelt definíciók szintetizálásával. Továbbá összefoglalják a szolgáltató robotok által betölthető munkaköröket és az általuk elvégezhető feladatokat.

Kulcsszavak: szolgáltató robot, robot munkaerő, robot dolgozó, negyedik ipari forradalom, Ipar 4.0

Service robots are able to perform increasingly sophisticated tasks, both in terms of physical and cognitive activities. Demand for them is growing globally, well supported by projections that by 2025, 85 percent of consumer interactions will take place without human employees. The introduction of service robots is thus becoming more common in various industries. The aim of this article is to define service robots and to review their application possibilities, for which the authors conducted a systematic literature search. In this article, after the introduction, the authors present the method of literature research, then they define the concept of service robots by synthesizing the definitions found in the reviewed literature and summarize the jobs that could be filled by service robots and the tasks they can perform.

Keywords: service robot, robot workforce, robot worker, Fourth Industrial Revolution, Industry 4.0

Finanszírozás/Funding:

A szerzők a tanulmány elkészítésével összefüggésben nem részesültek pályázati vagy intézményi támogatásban. The authors did not receive any grant or institutional support in relation with the preparation of the study.

\section{Szerzők/Authors:}

Pistrui Bencea (pbence0202@gmail.com) PhD-hallgató; Harmat Vandaa (vanda.harmat@uni-corvinus.hu) egyetemi tanársegéd

aBudapesti Corvinus Egyetem (Corvinus University of Budapest) Magyarország (Hungary);

A cikk beérkezett: 2020. 06. 24-én, javítva: 2021. 05. 11-én és 2021. 10. 08-án, elfogadva: 2021. 10. 15-án.

The article was received: 24. 06. 2020, revised: 11. 05. 2021 and 08. 10. 2021, accepted: 15. 10. 2021.

\begin{abstract}
$\mathrm{A}$ szolgáltató robotok egyre szofisztikáltabb feladatokat képesek ellátni mind a fizikai, mind a kognitív tevékenységek tekintetében (Lu et al., 2020). Az irántuk való kereslet világszinten növekszik, amit jól alátámasztanak azok az előrejelzések is, amelyek alapján 2025-re a fogyasztói interakciók 85 százaléka emberi alkalmazott nélkül fog zajlani (Schneider, 2017). Míg korábban a robotizációs hullám leginkább az ipart érintette, napjainkban a szolgáltató robotok alkalmazása is egyre több területen
\end{abstract}

megjelenik (Writz et al., 2018; Marciniak, Móricz \& Baksa, 2020), köztük markánsan a turizmus-vendéglátás ágazatban. A Las Vegasban található The Mandarin Oriental Hotelben a humanoid Pepper robot üdvözli és informálja a vendégeket (Walsh, 2018). A Japánban található Henn na Hotel pedig a világ első szállodája, amely robot személyzettel rendelkezik, és ahol a vendégek választhatnak, hogy egy android női vagy egy dinoszaurusz robotnál jelentkeznek be érkezéskor (Kikuchi, 2018). A repülötere- 
ken is megjelentek a szolgáltató robotok, akik az utasokat informálják, továbbá karbantartási, és biztonsági feladatok ellátására alkalmazzák őket (Paluch, Wirtz \& Kunz, 2020). Az idegenforgalom mellett az egészségügyben is alkalmaznak szolgáltató robotokat, melynek az igényét a szektorban jelentkező munkaerőhiány és az elöregedő társadalom hívta életre. A Tokióban található Shintomi ápoló otthonban robotok segítenek a betegek mozgatásában, továbbá beszélgetőpartnerként szórakoztatják őket (Foster, 2018).

Az előzőekben tárgyaltak alapján látható, hogy a szolgáltató robotok számos feladatkört elláthatnak. Jelen cikk célja a szolgáltató robotok definiálása és alkalmazási lehetőségeik áttekintése, melyhez szisztematikus irodalomkutatást végeztünk. Fontos megjegyeznünk, hogy a szolgáltató robotok által betölthető munkakörök áttekintésére fókuszálunk. Az egészségügyben, terápiában alkalmazott, társas képességek magas szintjével rendelkező szolgáltató robot munkaerő nem képezi jelen vizsgálatunk tárgyát.

Cikkünkben a bevezetést követően elhelyezzük a jelenleg is zajló jelenségek kontextusában a robotokat, melyhez bemutatjuk a negyedik ipari forradalmat és az Ipar 4.0 kontextusát, illetve az ehhez kapcsolódó technológiák feltételeit és jellemzőit. Ráfókuszálunk a negyedik ipari forradalomban alkalmazott robotokra, és azon belül leszükítjük kutatásunkat a szolgáltató robotokra. Ezután a felvezető rész után bemutatjuk az irodalomkutatás módszerét, amely föképp Okoli \& Schabram (2010) ajánlásait veszi figyelembe. Az eredmények fejezetben meghatározzuk a szolgáltató robotok fogalmát az áttekintett irodalomban fellelt definíciók szintetizálásával, továbbá összefoglaljuk a szolgáltató robotok iparági megjelenését és az általuk betölthető munkaköröket/feladatokat.

\section{Negyedik ipari forradalom és Ipar 4.0}

A negyedik ipari forradalom elnevezést a Világgazdasági Fórum (WEF) használta először 2016-ban, mely alatt az iparban és a digitális világban végbemenő változásokat értette. Szintén ebben az évben publikálta a WEF Klaus Schwab könyvét „Negyedik ipari forradalom” címmel (Karabegović, Husak \& Predrag, 2019), melyre a témát kutatók gyakran hivatkoznak. Schwab meghatározásában a negyedik ipari forradalomban az egyének a digitális és az offline terek között mozognak, miközben csatlakoztatott technológiákat használnak életük menedzseléséhez (Miller, 2016).

A negyedik ipari forradalmat a technológiák összekapcsolódása jellemzi, amelyben elmosódnak a határok a fizikai, a digitális és a biológiai szférák között (Xu, David \& Kim, 2018). A negyedik ipari forradalom exponenciálisan gyorsul (Karabegović, 2017), valamint csaknem minden ország minden iparágára hatással van. A negyedik ipari forradalom hozta változások szélessége és mélysége a teljes termelési, menedzsment és irányítási rendszer átalakulását eredményezi (Schwab, 2015 idézi Xu, David \& Kim, 2018). Az ipari forradalmakat összességében a teljes gazdaságra és társadalomra ható jelenségként értelmezik, míg az Ipar 4.0 konkrétan egy gyártásiágazat-orientált megközelítés, amely technológiai nézőpontból a negyedik ipari forradalom része (Demeter \& Losonci, 2020). Losonci, Takács és Demeter (2019, p.190) definíciója alapján „,az Ipar 4.0 a technológiai lehetőségekre építve egyedi és digitális szolgáltatási tartalommal bővített terméket kínál, egy új értékláncot szervezve”. Cikkünkben a szolgáltató robotokat ebből a technológiai szempontból szeretnénk megvizsgálni és bemutatni helyüket a jelenlegi üzleti folyamatokban.

\section{A feltörekvő (exponenciális) technológiák}

A feltörekvő (exponenciális) technológiák fogalma, melynek általános, elfogadott definíciója nincs, az 1980-as évektől jelent meg a szakirodalomban, de szélesebb körben az 1990-es évek közepétől terjedt el. Jelen cikkben Rotolo-Hicks és Martin (2015) meghatározását alkalmazzuk, mely szerint a radikálisan új, viszonylag gyorsan növekedő, idővel bizonyos fokú koherenciával jellemezhető és a társadalmi-gazdasági szereplőket jelentősen érintő technológiákat nevezzük így, amelyek legjelentősebb hatásukat azonban csak a jövőben fogják kifejteni, így ez a fejlődő szakasz még bizonytalan és zavaros. Az előbb bemutatott megfogalmazás a fejlődő technológiák jellemzői köré épül, melyek a radikális újdonság, a viszonylag gyors növekedés, a koherencia, a kiemelkedő hatás, a bizonytalanság, továbbá a zavar. Halaweh (2013) az exponenciális technológiákkal kapcsolatban a bizonytalanságot és a gazdasági, illetve társadalmi szereplökre gyakorolt hatást emelte ki, azonban rávilágított más jellemzőkre is:

1. Bizonytalanság: a bizonytalanság kifejti a hatását több területen is (pl.: költségek, üzleti modellek, alkalmazási területek). Az idő múlásával a bizonytalansági tényezők csökkennek, ahogy egyre több és több területen használják ezeket a technológiákat.

2. Hálózati hatás: egy fejlődő technológia értéke nő, ha nő az azt használók száma.

3. Költségesség: a technológia birtoklása költséges, ahogy egy meglévő kifejlett technológia fejlődő technológiával való helyettesítése is.

4. Nem egyértelmü hatás: a technológia használata elött, illetve annak korai szakaszában nem egyértelmű a társadalmi és etikai változások hatása.

5. Hozzáférhetőség: általában csak bizonyos területen lehet hasznosítani egy bizonyos technológiát, vagy egy adott országon belül, amely kifejlesztette.

6. Vizsgálata és kutatása nem teljes mértékü: kevés egyelöre az akadémiai kutatások száma.

Az exponenciális technológiák többféle szempont szerint kategorizálhatók. A Gartner IT kutatócég az üzleti hatás (várható haszon mértéke), az elvárások, valamint az általános használatig várható idő mentén csoportosítja a technológiákat (Gartner, 2017). A WEF (2018) 12 fejlődő technológiát azonosított (1. táblázat), amelyek a jövő gyártótechnológiájára hatással lesznek, vagy teljesen átalakítják a régi bevett rendszereket. Mint láthatjuk, megjelenik a robotika a mesterséges intelligenciával együtt a fejlődő technológiák között. 
1.táblázat nyú és fajtájú mozgásra alkalmas az adott robotkar és a

\section{Fejlődő technológiák}

\begin{tabular}{|l|l|}
\hline $\begin{array}{l}\text { Mesterséges intelligencia és } \\
\text { robotika }\end{array}$ & $\begin{array}{l}\text { Energiagyüjtés, tárolás, } \\
\text { átjátszás }\end{array}$ \\
\hline $\begin{array}{l}\text { Mindenhol jelenlévő } \\
\text { összekapcsolt szenzorok }\end{array}$ & Új számítási technológiák \\
\hline $\begin{array}{l}\text { Virtuális és kiterjesztett } \\
\text { valóság }\end{array}$ & Biotechnológia \\
\hline Additív gyártási technológiák & Éghajlatmérnökség \\
\hline $\begin{array}{l}\text { Blockchain és elosztott } \\
\text { fökönyvi technológia }\end{array}$ & Neurotechnológia \\
\hline $\begin{array}{l}\text { Fejlett alapanyagok és } \\
\text { nanoalapanyagok }\end{array}$ & Ürtechnológia \\
\hline
\end{tabular}

Forrás: saját szerkesztés a WEF (2018) csoportosítása alapján

\section{A robotok fogalma és tipizálása}

Kerr (2014) szerint a robot egy mechanikus vagy virtuális intelligens ágens, amely automatikusan vagy irányítással végez feladatokat, általában távirányításban. A mechanikus robotok definiálásával több kutató és nemzetközi szervezet foglalkozott az elmúlt években. Az ő munkájukat egységesítette az ISO standardok alapján Estolatan et al. 2018-ban. A szerzők meghatározása szerint a mechanikus robot egy újraprogramozható többfunkciós kezelöegység, ami arra lett tervezve, hogy tárgyakat mozgasson programozott mozgásoknak megfelelően különféle feladatok elvégzése céljából, miközben információt gyüjt a környezetéről, melyekre intelligensen reagál.

A robotok tipizálása több szempont mentén történhet. Estolatan et al. (2018) három nézőpontot javasol a robotok csoportosításához, melyek a technológiai, az iparági felhasználás, valamint az interaktivitás. A technológiai nézöpont szerint további három lényeges tulajdonság van, amely meghatároz egy robotot. Az első az érzékelés, azaz, hogy milyen technológiával képes a robot a külvilágot értelmezni. A második az intelligencia, vagyis az, hogy milyen algoritmus, program és meghajtó rendszer alapján müködik. A harmadik pedig a mozgás, amely aszerint különbözteti meg a robotokat, hogy milyen irá- csukló.

Az iparági felhasználás nézőpontja a robotokat az alkalmazásuk célja szerint különíti el, melynek alapján ipari és szolgáltató robotokról beszélhetünk. Az ipari robotok és a szolgáltató robotok közötti legfontosabb különbség abban mutatkozik meg, hogy a szolgáltató robotok ipari automatizálásra nem alkalmazhatók (ISO 8373, 2012). A szolgáltató robot - definíciója szerint - hasznos feladatot lát el az emberekért, „félig vagy teljesen autonóm módon müködve annak érdekében, hogy az emberek jóllétéhez hozzájáruljon, a gyártási tevékenységet kivéve" (IFR). Az ipari robotok további csoportosítása a mozgásuk alapján, a szolgáltató robotoké pedig az alkalmazásuk kontextusa mentén történhet. Az ipari robotoknak három alapvető összetevője van: a manipulátor, a vezérlő és a szerszám (Singh \& Sellappan, 2013). A manipulátor a karból és a robot alapjából áll, továbbá itt található az energiaellátás is. A manipulátor az az egység, amely felel a robot mozgásáért. Az ipari robotok mozgása leírható a koordinátarendszerhez való viszonyukkal. Ez lehet hengeres, gömb alakú, antropomorf vagy descartes-i rendszerben értelmezett (International Federation of Robotics, 2016). A vezérlő adja a robot különlegességét, ugyanis ennek segítségével válnak képessé a szakemberek beállítani az éppen aktuális feladatok elvégzésére és később ezt újraprogramozni, amivel megteremtik a lehetőséget a sokoldalú felhasználásra. A szerszám pedig az az eszköz a roboton, amely elvégzi a vezérlőbe beprogramozott munkát legyen az fogás, festés, csiszolás stb. Különböző feladatokhoz természetesen különböző szerszámokra van szükség, de ezek biztosítják, hogy a különféle feladatokat végre is tudja hajtani a robot a gyakorlatban (Singh \& Sellappan, 2013).

A szolgáltató robotok esetében megkülönböztethetjük a személyes szolgáltató robotokat (personal SR), valamint a professzionális szolgáltató robotokat (professional SR). A professzionális szolgáltató robotok üzleti környezetben látják el feladatukat (pl.: szállító robotok, rehabilitációs robotok), szemben a személyes szolgáltató robotokkal (robotporszívó otthoni használatra) (Estolatan et al., 2018).

\section{Az ipari és szolgáltató robotok tipizálása és alkalmazási területei}

\begin{tabular}{|l|l|l|}
\hline IPARÁGI FELHASZNÁLÁS & \multicolumn{1}{|c|}{ Kategória } & \multicolumn{1}{c|}{ Alkalmazás } \\
\hline \multirow{5}{*}{ ipari robot } & lineáris robotok & lézeres hegesztés, tömítés, nyomás, müanyag fröccsöntés \\
\cline { 2 - 3 } & SCARA robotok & összeszerelés, csomagolás \\
\cline { 2 - 3 } & csuklós robotok & festés, csomagolás, fémöntési munkák, palettázás, hegesztés \\
\cline { 2 - 3 } & párhuzamos robotok & szedés és elhelyezés, összeszerelés, kezelés \\
\cline { 2 - 3 } & hengeres robotok & orvosi robotok \\
\cline { 2 - 3 } & egyéb & $\begin{array}{l}\text { veszélyes környezeti müködés, víz alatti, atmoszférabeli, ürbeli, fel- } \\
\text { használás }\end{array}$ \\
\cline { 2 - 3 } & nem osztályozott robotok & automata vezérelt jármüvek \\
\hline \multirow{2}{*}{ szolgáltató robot } & személyes & háztartás \\
\cline { 2 - 3 } & professzionális & üzleti környezet \\
\hline
\end{tabular}


Interaktivitás tekintetében a csoportosítás szempontja, hogy a robot milyen szerepet tölt be az ember mellett. Ezen nézőpont szerint megkülönböztethető a robot aszszisztensi szerepköre, melynek értelmében a robot segíti az ember munkáját, de közös munkavégzésről ez esetben nem beszélhetünk. A második csoportba a kollaboratív robotok (cobots) tartoznak, amelyek az emberek partnereként müködnek a közös munkavégzés során, ugyanis az emberrel ugyanazon a feladaton dolgoznak. S végül a harmadik kategóriát az autonóm robotok képviselik, amelyek feladatuk ellátása során konstans emberi felügyeletet nem igényelnek, a müködésükhöz emberi beavatkozás tehát nem szükséges.

Az előző csoportosítási szempontok mellett fontosnak tartjuk még kiemelni a robotok megjelenése (fizikai tulajdonságai) szerinti kategorizálás lehetőségét. A robotok lehetnek fizikailag megtestesültek vagy virtuális entitások. Az utóbbiak közé sorolhatók a robotizált folyamatautomatizálásban alkalmazott szoftverrobotok, illetve a chatbotok. A fizikailag megtestesült robotok - külsejüket tekintve - hasonlíthatnak az állatokhoz (animoid) vagy az emberekhez (humanoid). A humanoid robotok végtagokkal és fejjel rendelkeznek. Az android robotok ennél is emberszerübbek, hiszen szilikon bőrük és mühajuk is van. A geminoid olyan emberszerü robot, amelyet élö ember alapján mintáztak.

Kutatásunkban a 2. táblázatban szereplő szolgáltató robotok professzionális felhasználásával foglalkozunk üzleti környezetben.

\section{Az irodalomkutatás módszere}

A szolgáltató robotok definiálásához és alkalmazási területük áttekintéséhez szisztematikus irodalmi áttekintést végeztünk, melyet Fink (2005, p.3, p.17) a következőképpen határoz meg: „szisztematikus, explicit, átfogó”, valamint a megismételhetőséget biztosító irodalomkutatási módszer, melynek célja a kutatók, az akadémikusok és a gyakorlati szakemberek írásainak azonosítása, értékelése, valamint szintetizálása (Okoli \& Schabram, 2010, p.4). A szisztematikus irodalmi áttekintés kötött szabályok mentén zajlik, melyek követése kulcsfontosságú a szakszerü, transzparens és megismételhető irodalomkutatás elvégzéséhez. A bevezetésben megfogalmazott kutatási céljaink megvalósításának érdekében Okoli \&

3. táblázat

\section{A szisztematikus irodalomkutatás lépései}

\begin{tabular}{|l|}
\hline 1. A kutatási cél meghatározása \\
\hline 2. A kutatási protokoll leírása \\
\hline 3. A keresési stratégia részletes bemutatása \\
\hline 4. A kiválasztás kritériumainak bemutatása \\
\hline 5. A kiválasztott tanulmányok minőségének értékelése \\
\hline 6. A kiválasztott cikkek elemzése \\
\hline 7. Az áttekintés megírása \\
\hline
\end{tabular}

Forrás: saját szerkesztés Okoli \& Schabram (2010, p.4) alapján
Schabram (2010, p.7) módszertani ajánlását követtük, akik a szisztematikus irodalmi áttekintés elkészítésének nyolc lépését határozták meg (3. táblázat).

\section{Adatgyűjtés - keresési stratégia}

Az irodalomkutatást a SCOPUS adatbázisban végeztük a „service robot” kulcsszóval 2020. november 13-án. A szürők tekintetében beállítottuk a publikációk megjelenésére vonatkozóan, hogy az angol nyelvü, 2016 és 2020 között publikált folyóiratcikkek szerepeljenek a találati listában. Emellett szükítettük a keresés területeit a következőkre: Business Management and Accounting, Social Sciences. Így a találatok száma összesen 76 lett. Kutatásunk fókuszába az üzleti életben alkalmazott robotokat tettük, így hatásuk a társadalomra a különféle szolgáltató iparágakban nem elhanyagolható. Emiatt választottuk ki a Social Sciences kritériumot is, habár így például viselkedéstani cikkek is bekerültek az első körös absztraktok közé. Azonban több, a robotok társadalmi elfogadásával kapcsolatos cikk is előtérbe került, ami az iparágankénti felhasználásra engedett kitekinteni. A különféle közgazdasági modellező robotok és banki tőzsdei robotok nem képezték kutatásunk tárgyát, mivel azok mechanikája, müködési elve és az emberek közötti társas interakciókhoz való kapcsolata eltér az általunk vizsgált szolgáltató robotoktól (algoritmusokon és historikus adatokon alapuló előrejelzések, pl. csődelőrejelző modellek stb.; vannak mesterséges intelligenciával megtámogatott szoftverek is). További kutatási korlátot jelentett az adatgyüjtés során, hogy több konkrét iparági kutatás nem foglalkozik külön a robotok tipizálásával, így gyüjtőnévként robotként hivatkozik a szolgáltató és az ipari robotokra egyaránt. Ez nehézséget jelent a mostani kutatásban, amit a későbbi iparágspecifikus kutatások során figyelembe kell venni.

\section{A kiválasztás kritériumai}

A 4. táblázat mutatja be az áttekintésre alkalmas folyóiratcikkek kiválasztásának kritériumait. A kutatás szempontjából relevánsnak ítélt folyóiratcikkeknek szorosan vagy részben kell kapcsolódniuk a kutatási célhoz. A szorosan kapcsolódó (SZK) cikkek jellemzője, hogy különféle definíciókat sorakoztatnak fel a szolgáltató robotokkal kapcsolatban és tárgyalják néhány alkalmazási területüket is. A részben kapcsolódó (RK) tanulmányokban legalább az előző feltételek egyike megjelenik. A nem kapcsolodó (NK) tanulmányok körét több csoportra lehet bontani: a keresés eredményeként megjelentek olyan publikációk, amelyek inkább a technológiai megvalósítást helyezték a fókuszba, és a konkrét üzleti felhasználás nem került előtérbe, míg más írások esetében a szolgáltató robotok alkalmazási módjának tárgyalása nem felelt meg az üzleti kritériumnak (hadászat, gyógyászat, pszichológia stb.). Emellett a találati listába kerültek olyan cikkek is, amelyek a szolgáltató robotokról csupán említést tettek. 
4. táblázat

A folyóiratcikkek kiválasztási kritériumai

\begin{tabular}{|c|c|}
\hline Kritérium & Kritérium leírása \\
\hline $\begin{array}{c}\text { Szorosan } \\
\text { kapcsolódik } \\
\text { (SZK) }\end{array}$ & $\begin{array}{c}\text { Megjelenik a szolgáltató robot definíciója. } \\
\text { és }\end{array}$ \\
$\begin{array}{c}\text { Megjelenik a szolgáltató robot alkalmazási } \\
\text { területe. }\end{array}$ \\
$\begin{array}{c}\text { Részben } \\
\text { kapcsolódik } \\
(\mathrm{RK})\end{array}$ & $\begin{array}{c}\text { Megjelenik a szolgáltató robot definíciója. } \\
\text { vagy }\end{array}$ \\
& $\begin{array}{c}\text { Megjelenik a szolgáltató robot alkalmazási } \\
\text { területe. }\end{array}$ \\
$\begin{array}{c}\text { Nem } \\
\text { kapcsolódik } \\
\text { (NK) }\end{array}$ & $\begin{array}{c}\text { Nem tartalmaz definíciót a szolgáltató robotra } \\
\text { vonatkozóan. } \\
\text { vagy }\end{array}$ \\
& $\begin{array}{c}\text { alkalmazási területeit. } \\
\text { vagy }\end{array}$ \\
& $\begin{array}{c}\text { Nem üzleti felhasználás jellemzi a robotokat } \\
\text { (pl. hadászat, gyógyítás) }\end{array}$ \\
\hline
\end{tabular}

Forrás: saját szerkesztés Liao et al. (2017, p. 3611) alapján

\section{A cikkek kiválasztásának folyamata}

Az 1. ábra bemutatja a kutatás során elemzett cikkek kiválasztásának folyamatát. A SCOPUS adatbázisban a ,,service robot ” kulcsszóra 4962 publikáció jelent meg. A szürők beállítása után a találatok száma 76-ra redukálódott. Az absztraktok áttekintése során alkalmaztuk a kiválasztási kritériumokat, melynek eredményeként 33 tanulmányt zártunk ki. Az absztraktok alapján 43 cikket ítéltünk alkalmasnak, melyek elolvasásakor újra alkalmaztuk a kiválasztási kritériumokat, és további 18 cikket zártunk ki. Így a szisztematikus irodalomkutatás eredményeként öszszesen 25 folyóiratcikket emeltünk be az elemzésbe.

\section{A folyóiratcikkek kiválasztásának PRISMA folyamatábrája}

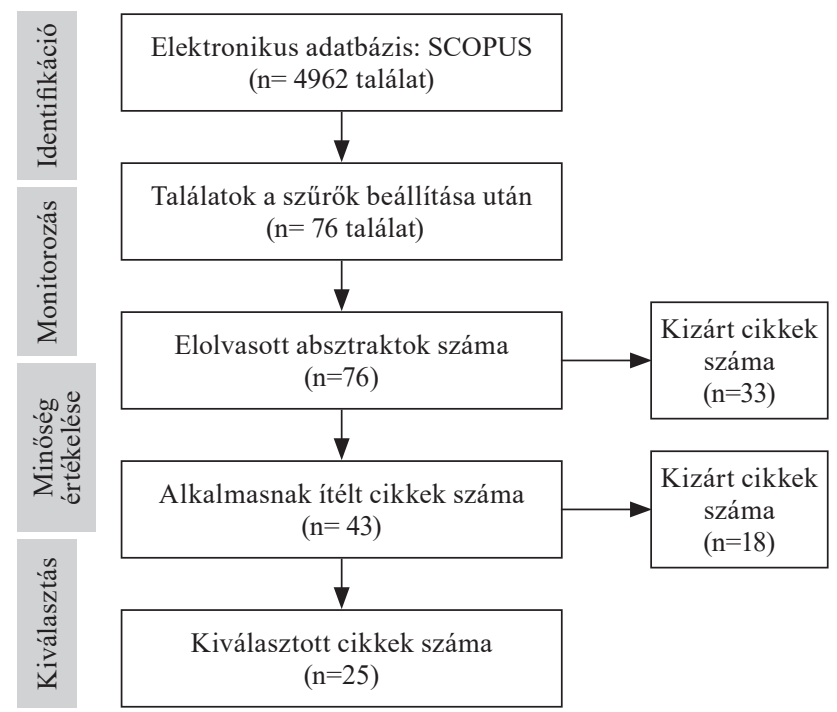

Forrás: saját szerkesztés Gallagher, Kadokura, Eckert, Mounier-Jack \& Ross (2016, p. 4) alapján

\section{Eredmények}

\section{Leíró elemzés}

Jelen fejezetben bemutatjuk a kiválasztott cikkek leíró elemzését. A szakirodalmi áttekintésbe összesen 25 folyóiratcikket emeltünk be, amelyek megjelenés szerinti eloszlását az 5. táblázat szemlélteti. A táblázat alapján látható, hogy legnagyobb arányban a turizmus és a vendéglátás területén születtek a szolgáltató robotokkal kapcsolatos tanulmányok. Látható, hogy a turizmus és vendéglátás fókuszú folyóiratok, cikkek mellett megtalálhatók a szolgáltatás-, marketing- és szervezeti fókuszú folyóiratok is. Az elkövetkezendő időszakban a konferenciatanulmányok nagy száma miatt várható további cikkek megjelenése iparágtematikus folyóiratokban, de a közeljövőben még továbbra is a turizmus-vendéglátásban alkalmazott szolgáltató robotokkal kapcsolatos cikkek lesznek túlsúlyban.

5. táblázat

\section{Az elemzésbe beemelt cikkek a megjelenés helye szerint}

\begin{tabular}{|l|c|}
\hline \multicolumn{1}{|c|}{ Folyóirat } & $\begin{array}{c}\text { Cikkek } \\
\text { száma }\end{array}$ \\
\hline $\begin{array}{l}\text { International Journal of Contemporary Hospitality } \\
\text { Management }\end{array}$ & 5 \\
\hline International Journal of Hospitality Management & 3 \\
\hline Current Issues in Tourism & 2 \\
\hline Electronic Markets & 1 \\
\hline Service Business & 1 \\
\hline Journal of Service Management & 2 \\
\hline The Service Industries Journal & 2 \\
\hline Technology in Society & 2 \\
\hline Journal of Turism Futures & 1 \\
\hline Annals of Turism Research & 2 \\
\hline Journal of Services Marketing & 1 \\
\hline Organizational Dynamics & 1 \\
\hline Industria Textilia & 1 \\
\hline Industrial Management and Data Systems & 1 \\
\hline
\end{tabular}

Forrás: saját szerkesztés

Az elemzett cikkek évenkénti eloszlását a 6 . táblázat szemlélteti. A kiválasztott folyóiratcikkek 80\%-át 2020ban publikálták, összefüggésben a Covid-19 okozta globális helyzettel, amit később részletesebben kifejtünk. A 2020 előtti években kifejezetten a szolgáltató robotok definiálását, tipizálását célzó cikket csupán elvétve publikáltak. Ez is mutatja, hogy a negyedik ipari forradalom korában alkalmazott robotok vizsgálata kapcsán kutatási rések azonosíthatók, de most értünk el egy inflexiós ponthoz. Ezek alapján fontos figyelmet fordítanunk a szolgáltató robotokra. 
6. táblázat

A kiválasztott cikkek eloszlása a megjelenés éve szerint

\begin{tabular}{|c|c|c|c|c|}
\hline $\mathbf{2 0 1 6}$ & $\mathbf{2 0 1 7}$ & $\mathbf{2 0 1 8}$ & $\mathbf{2 0 1 9}$ & $\mathbf{2 0 2 0}$ \\
\hline 0 & 2 & 1 & 2 & 20 \\
\hline
\end{tabular}

Forrás: saját szerkesztés

\section{Tartalomelemzés}

\section{A szolgáltató robotok definiálása}

A 7. táblázat összefoglalja az irodalmi áttekintés eredményeként megjelenő szolgáltató robot definíciókat, melyek közül néhányat kiemelünk jelen fejezetben. Belanche, Casaló, Flavián \& Schepers (2020a) a szolgáltató robotok fogalma alatt azokat a frontline feladatokra alkalmazható,

\section{Az áttekintett folyóiratcikkekben bemutatott szolgáltató robot definíciók}

\begin{tabular}{|c|c|c|}
\hline Szerző & Bemutatott definíció szerzője & Definíció elemei \\
\hline \multirow{2}{*}{$\begin{array}{l}\text { Belanche, } \\
\text { Casaló, Flavián } \\
\& \text { Schepers } \\
\text { (2020a) }\end{array}$} & Interantional Federation of Robotics (2016) & $\begin{array}{l}\text { (1) Az emberek számára hasznos tevékenységek végzése, } \\
\text { (2) kivéve az ipari automatizációs alkalmazásokat }\end{array}$ \\
\hline & Wirtz et al. (2018) & $\begin{array}{l}\text { (1) Rendszeralapú, autonóm és adaptálható interfészek } \\
\text { (2) Interaktálnak, kommunikálnak és szolgáltatásokat nyújtanak a } \\
\text { fogyasztóknak }\end{array}$ \\
\hline Cha (2020) & Ivanov et al. (2017) & (1) Az ember támogatása társas interakciókkal \\
\hline \multirow{8}{*}{$\begin{array}{l}\text { Chiang \&Trimi } \\
(2020)\end{array}$} & Haidegger et al. (2013) & \multirow{8}{*}{$\begin{array}{l}\text { (1) Mechanikai eszközök } \\
\text { (2) Az emberi viselkedést utánozzák } \\
\text { (3) Autonóm vagy félig autonóm módon müködnek } \\
\text { (4) Szolgáltatást nyújtanak az embernek } \\
\text { (5) Az ipari robotoktól külső megjelenésükben és funkcióikban kü- } \\
\text { lönböznek } \\
\text { (6) Ismétlődő, nehéz, összetett, koszos, veszélyes és időigényes fel- } \\
\text { adatok automatizálására alkalmazzák } \\
\text { (7) Fajtái: professzionális és személyes szolgáltató robotok }\end{array}$} \\
\hline & Interantional Federation of Robotics (2016) & \\
\hline & Lechevalier et al. (2014) & \\
\hline & Calderone (2019) & \\
\hline & Matarić (2017) & \\
\hline & Lee et al. (2009) & \\
\hline & Darling (2012) & \\
\hline & Reiser et al. (2009) & \\
\hline $\begin{array}{l}\text { Lu, Cai \& } \\
\text { Gursoy (2019) }\end{array}$ & Writz et al. (2018) & (1) AI alapú szolgáltató ágensek \\
\hline \multirow[t]{2}{*}{ Reis et al. (2020) } & Bowen \& Morosan (2018) & \multirow{2}{*}{$\begin{array}{l}\text { (1) Fizikailag testet öltött mesterségesen intelligens ágens } \\
\text { (2) Hatással vannak a fizikai világra } \\
\text { (3) Alaptevékenységeket támogatnak }\end{array}$} \\
\hline & Kachouie's et al (2014) & \\
\hline \multirow{2}{*}{$\begin{array}{l}\text { Rosete et al. } \\
(2020)\end{array}$} & Kuo, Chen, Tseng (2017) & \multirow{2}{*}{$\begin{array}{l}\text { (1) Okos, programozható eszközök } \\
\text { (2) Érzékelnek, gondolkoznak } \\
\text { (3) Segédkeznek az embereknek }\end{array}$} \\
\hline & Engelhardt (1990) & \\
\hline \multirow{2}{*}{$\begin{array}{l}\text { Shin \& Jeong } \\
(2020)\end{array}$} & International Federation of Robotics, 2016 & \multirow{2}{*}{$\begin{array}{l}\text { (1) Hasznos feladatokat látnak el emberek vagy felszerelések számá- } \\
\text { ra, } \\
\text { (2) kivéve az ipari automatizációs alkalmazásokat }\end{array}$} \\
\hline & Tung and Law, 2017 & \\
\hline \multirow{2}{*}{$\begin{array}{l}\text { Tung \& Law. } \\
\text { (2017). }\end{array}$} & Interantional Federation of Robotics (2016) & \multirow{2}{*}{$\begin{array}{l}\text { (1) Emberek számára hasznos tevékenységek végzése } \\
\text { (2) kivéve az ipari automatizációs alkalmazásokat } \\
\text { (3) Robotok és emberek felismerik egymást és interakcióba } \\
\text { lépnek egymással }\end{array}$} \\
\hline & Dautenhahn, 1999 & \\
\hline \multirow{3}{*}{$\begin{array}{l}\text { Tussyadiah, I. } \\
\text { (2020) }\end{array}$} & $\begin{array}{l}\text { International Organization for Standardiza- } \\
\text { tion, } 2012\end{array}$ & \multirow{3}{*}{$\begin{array}{l}\text { (1) Emberek számára hasznos tevékenységek végzése } \\
\text { (2) kivéve az ipari automatizációs alkalmazásokat } \\
\text { (3) Bizonyos fokú autonómiával rendelkeznek } \\
\text { (4) Emberi beavatkozás nélkül elvégzik a feladatot } \\
\text { (5) Ember helyett számítógépes vezérlés }\end{array}$} \\
\hline & International Federation of Robotics, 2016 & \\
\hline & Colby, Mithas \& Parasuraman, 2016 & \\
\hline \multirow{4}{*}{$\begin{array}{l}\text { Writz et al. } \\
\text { (2018) }\end{array}$} & Allen et al., 2000 & \multirow{4}{*}{$\begin{array}{l}\text { (1) Sorozatos komplex tevékenységek elvégzése } \\
\text { (2) Önálló döntéshozatal érzékelés által } \\
\text { (3) Adaptálódnak szituációkhoz korábbi tapasztalatok alapján } \\
\text { (4) Élvonalbeli alkalmazáskor social robotként funkcionálnak } \\
\text { (5) Képesek azt éreztetni a felhasználókkal, hogy társas entitások }\end{array}$} \\
\hline & Pagallo, 2013 & \\
\hline & Singer, 2009 & \\
\hline & van Doorn et al., 2017 & \\
\hline $\begin{array}{l}\text { Xu, Stienmetz \& } \\
\text { Ashton (2020). }\end{array}$ & $\begin{array}{l}\text { International Organization for Standardiza- } \\
\text { tion, } 2012\end{array}$ & $\begin{array}{l}\text { (1) Lényeges feladatokat végeznek el embereknek } \\
\text { (2) Bizonyos fokú autonómiával rendelkeznek } \\
\text { (3) Emberi beavatkozás nélkül elvégzik a feladatot }\end{array}$ \\
\hline
\end{tabular}

Forrás: saját szerkesztés 
autonóm technológiákat értik, amelyek valamilyen fizikai interfésszel rendelkeznek. Lu, Cai \& Gursoy (2019, p. 37) definíciója szerint a szolgáltató robot képes autonóm döntések meghozatalára a szenzorai által nyert adatok alapján, mely lehetővé teszi alkalmazkodását az eltérő szituációkhoz. Cha (2020) meghatározásában a szolgáltató robot alkalmazásának célja az ember támogatása társas interakcióval.

A szolgáltató robot definíciók mellett az áttekintett szakirodalomban különböző szempontú csoportosításokat találtunk. Chiang \& Trimi (2020) cikkükben megkülönböztetik a professzionális és a személyes szolgáltató robotok csoportját. A professzionális szolgáltató robotokat a hatékonyság, illetve a termelékenység fokozása céljából alkalmazzák a vállalatokban (Calderone 2019; Lee et al., 2009), ezzel szemben a személyes szolgáltató robotok az egyén számára nyújtanak asszisztenciát (Darling, 2012; Reiser et al., 2009). Lu et al. (2019) a szolgáltató robotokat fizikai megjelenésük alapján tipizálják, mely klasszifikáció szerint a szolgáltató robotok lehetnek fi-
A szisztematikus irodalomkutatás során elemzett definíciók alapján megállapíthatjuk, hogy azokat a mesterséges intelligenciával és társas képességek magas szintjével rendelkező, ipari robotoktól külső megjelenésükben eltérő fizikailag megtestesült vagy szoftverrobotokat nevezzük szolgáltató robotoknak, amelyek tevékenységükkel az embereket támogatják. A szoftverrobotok mesterséges intelligenciával és valamilyen fokú autonómiával rendelkeznek, azonban azok a szoftverrobotok melyek nagymértékü hiányt szenvednek a társas képességekben, az értelmezésünk szerint nem tekinthetőek szolgáltató robotoknak. Wirtz et al. (2018) a szolgáltató robotok hatását makro- (társadalom), mezo- (piacok) és mikro- (vállalat, fogyasztó, munkavállalók) környezetre egyaránt vizsgálja. A robotok megtestesülése szempontjából ő megkülönböztet virtuális és fizikai szolgáltató robotokat, az elvégzett feladat alapján kézzelfogható és megfoghatatlan szolgáltatásokat, illetve a szolgáltatások címzettje terén embereket és tárgyakat. E megjelenéseket összegzi példákkal a 2. ábra.

\section{A szolgáltató robotok megkülönböztetése feladattípus és a szolgáltatás címzettje alapján}

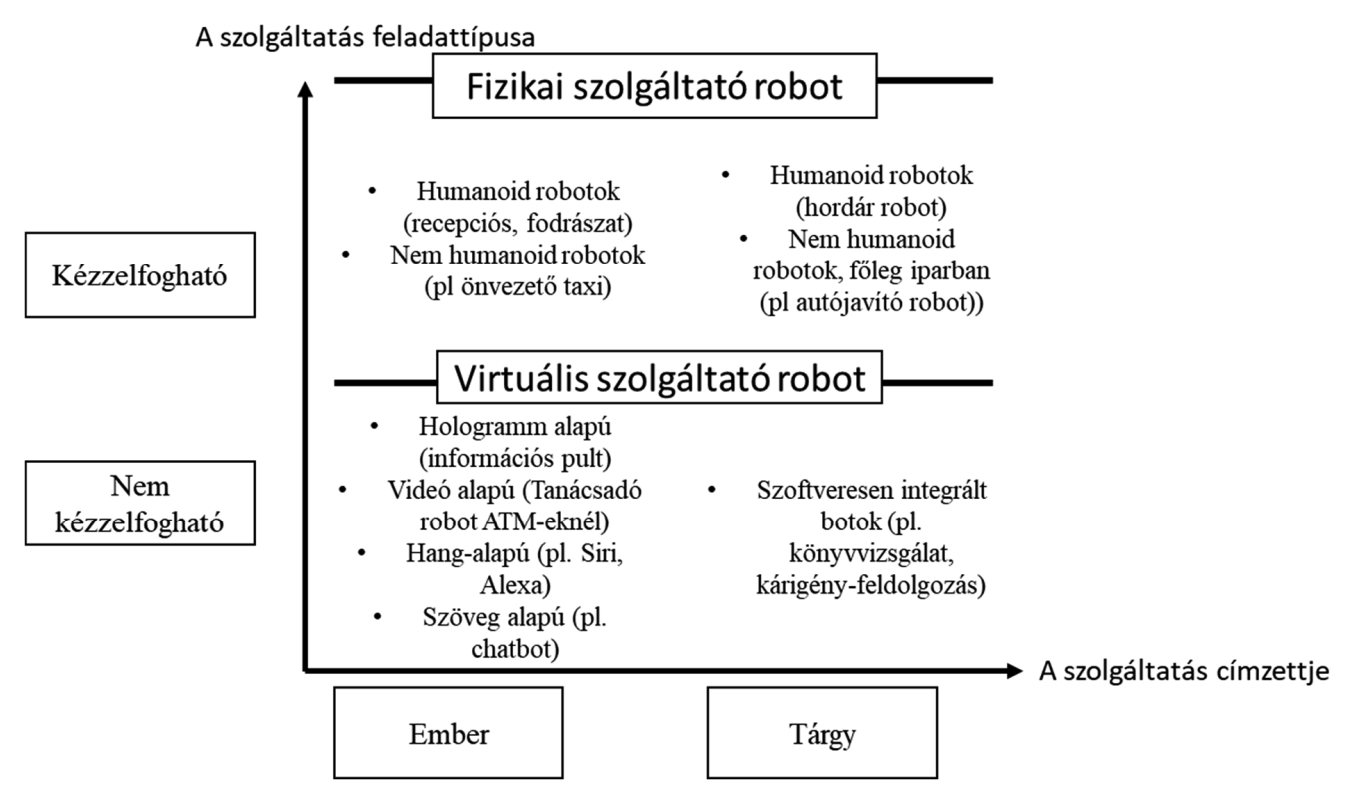

Forrás: Wirtz et al. (2018)

zikailag megtestesült robotok vagy virtuális ágensek. A fizikailag megtestesült szolgáltató robotok nagyrészt humanoid robotok, azaz felépítésük az emberére hasonlít, és leginkább kognitív-analitikai vagy emocionális-társas feladatokat látnak el. A virtuális szolgáltató robotok között szerepelnek többek között az ügyfélszolgálat, a banki szolgáltatások és az idegenforgalom területén alkalmazott chatbotok.

A legtöbb szerző az International Federation of Robotics és az International Organization for Standardization definíciójából indult ki, de többen merítettek Wirtz és szerzőtársai munkájából (2018). Külön érdekesség, hogy utóbbiak viszonylag régebben publikált cikkeket vettek alapul definíciójuk meghatározásához.

\section{A szolgáltató robotok által betölthető munkakörök}

Frey és Osborne 2017-ben megjelent cikke foglalkozik a különböző munkakörök automatizálhatóságának valószínüségeivel, melyet összeköt azzal, hogy az ehhez szükséges autonómiával, rugalmassággal és hatékonysággal rendelkező robotok kereskedelmileg elérhetővé válnak. Az irodalom áttekintése során láthatóvá váltak a szolgáltató robotok lehetséges alkalmazási területei, melyek között szerepelnek a banki szolgáltatások (Belanche et al., 2020a; Castillo et al., 2020), a turizmus-vendéglátás (Lu et al., 2019; Belanche et al., 2020; Cha, 2020; Chiang \& Trimi, 2020; Choi et al., 2020; Ho et al., 2020), a közleke- 
dés (Chiang \& Trimi, 2020), az ügyfélszolgálat, valamint a kiskereskereskedelem (Belanche et al., 2020a, Castillo et al., 2020). A 8. táblázat szemlélteti, hogy a szolgáltató robotok mely munkakörök ellátására képesek.

8. táblázat

\section{A szolgáltató robotok által betölthető munkakörök}

\begin{tabular}{|c|c|}
\hline Munkakör/feladat & Szerző \\
\hline pénzügyi tanácsadás & \multirow{2}{*}{$\begin{array}{l}\text { Belanche, Casaló, Flavián } \\
\& \text { Schepers (2020a) } \\
\text { Castillo, Canhoto \& Said } \\
(2020)\end{array}$} \\
\hline $\begin{array}{l}\text { számlanyitással, elvesztett } \\
\text { hitelkártyával kapcsolatos } \\
\text { asszisztencia }\end{array}$ & \\
\hline fintech támogatás & $\begin{array}{l}\text { Castillo, Canhoto \& Said } \\
(2020)\end{array}$ \\
\hline csomag összekészítés & $\begin{array}{l}\text { Belanche, Casaló, Flavián } \\
\text { \& Schepers (2020a) } \\
\text { Castillo, Canhoto \& Said } \\
(2020)\end{array}$ \\
\hline repülőtéri informálás & Chiang \&Trimi (2020) \\
\hline ügyfélszolgálat & $\begin{array}{l}\text { Choi, Oh, Choi \& Kim } \\
(2020)\end{array}$ \\
\hline tanácsadás, értékesítés, foglalás & $\begin{array}{l}\text { Ho, Tojib \&Tsarenko } \\
(2020)\end{array}$ \\
\hline felszolgáló & $\begin{array}{l}\text { Belanche, Casaló \& } \\
\text { Flavián (2020b) } \\
\text { Choi, Oh, Choi \& Kim } \\
(2020)\end{array}$ \\
\hline takarító & $\begin{array}{l}\text { Choi, Oh, Choi \& Kim } \\
(2020) \\
\text { Belanche, Casaló \& } \\
\text { Flavián }(2020)\end{array}$ \\
\hline recepciós & $\begin{array}{l}\text { Ho, Tojib \&Tsarenko } \\
\text { (2020), Shin, H. H., \& } \\
\text { Jeong, M. (2020) }\end{array}$ \\
\hline concierge & $\begin{array}{l}\text { Choi, Oh, Choi \& Kim } \\
(2020)\end{array}$ \\
\hline chef & $\begin{array}{l}\text { Choi, Oh, Choi \& Kim } \\
(2020)\end{array}$ \\
\hline barista & Lu, Cai \& Gursoy (2019) \\
\hline csomaghordó & Lu, Cai \& Gursoy (2019) \\
\hline ételfutár & Cha (2020) \\
\hline szobaszerviz & $\begin{array}{l}\text { Choi, Oh, Choi \& Kim } \\
(2020)\end{array}$ \\
\hline textilipari segédkezés & Yanhui et al. (2020) \\
\hline $\begin{array}{l}\text { fizikai távolságtartás a } \\
\text { turizmusban }\end{array}$ & $\begin{array}{l}\text { Seyitoğlu \& Ivanov } \\
\text { (2020b) }\end{array}$ \\
\hline $\begin{array}{l}\text { turinform (idegenvezetés, } \\
\text { általános információ szolgálat) }\end{array}$ & $\begin{array}{l}\text { Tussyadiah (2020), } \\
\text { Tussyadiah, Zach, \& } \\
\text { Wang (2020) } \\
\end{array}$ \\
\hline $\begin{array}{l}\text { információszolgálat hotelekben, } \\
\text { kiskereskedelmi üzletekben; } \\
\text { rendelésfelvétel éttermekben }\end{array}$ & $\begin{array}{l}\text { van Pinxteren (2019) } \\
\text { gyüjtése }\end{array}$ \\
\hline
\end{tabular}

Forrás: saját szerkesztés

Kutatásunk alapján megállapítható, hogy jelenleg a legelterjedtebb kutatások a turizmus és a vendéglátás területén alkalmazott szolgáltató robotokra fókuszálnak. Ennek a szakirodalom több magyarázatot is tulajdonít. A legtöbb publikáció nem véletlenül a 2020-as évben jelent meg. A koronavírus okozta bizonytalanság a teljes turizmus és vendéglátás szektort mélyen érintette, így a távolságtartás, higiénia és az ember-ember interakciók csökkentése ezt az iparágat állította a szolgáltató robotokkal kapcsolatos kutatások középpontjába (Seyitoğlu \& Ivanov (2020b). Ennek megfelelően a társadalmi hatások és a bizalom is a középpontba kerültek, mivel emiatt egyre több ember fog akár az utazásai, akár a hétköznapi bevásárlásai alkalmával robotokkal kapcsolatba kerülni (van Pinxteren et al., 2019; Tussyadiah, Zach \& Wang, 2020). A fogyasztók attitüdje a robotok elfogadásában a legfontosabb elem, amelyet a legjobban az észlelt hasznosság és az érzékelt érték fog befolyásolni (Zhong et al., 2019). A bizalom növekedésével a fogyasztói élmény magasabb minőségüvé válik. Azonban néhány szolgáltatástípusnál (egészségügy) vagy bizonyos fogyasztói karakterisztikáknál (szorongás) jobban fel kell ruházni a robotokat társas képességekkel (van Pinxteren et al., 2019). Mindezek miatt egyre inkább fókuszba kerülnek a kifejezetten ember-robot interakciókra épülő kutatások (Tung \& Law 2017).

\section{Összegzés}

Jelen cikk fókuszában a robotok, mint a negyedik ipari forradalom meghatározó technológiái álltak, azon belül is a szolgáltató robotokra helyeztük a hangsúlyt. Szakirodalmi áttekintésünkben elsőként a negyedik ipari forradalmat, illetve az exponenciális technológiákat definiáltuk, tekintettel arra, hogy a modern ipari és szolgáltató robotok az Ipar 4.0 feltörekvő technológiájaként értelmezhetők.

A szolgáltató robotok definiálásánál arra törekedtünk, hogy láthatóvá váljon egyértelmü elkülönülésük az ipari robotoktól. A szolgáltató robotok iparági felhasználása szintén cikkünk tárgyát képezte, hogy ezzel céltudatosabb jövőbeli kutatásokat alapozzunk meg.

A szolgáltató robotok implementálása üzleti környezetben elkezdődött. Jelenleg a legnagyobb hatását a turizmusban és a vendéglátásban fejti ki, de a kutatások rávilágítanak, hogy elterjedése várható a kiskereskedelem, bankszektor, egészségügy, idősgondozás, szállítmányozás iparágakban is. A cégek a költséghatékony szolgáltatási kiválóságra törekednek, így a mesterséges intelligenciával rendelkező szolgáltató robotok elterjedése várható a legtöbb üzleti modellben (Wirtz, 2020). Több kutatás is kiemelt figyelmet fordít az ember-robot interakciókra, ezáltal az elfogadás, a bizalom és a fogyasztói élmény a középpontba kerül. Vezetői szempontból az alkalmazottak és a szolgáltató robotok együttes használata lehetővé teszi a vendéglátó társaságok számára, hogy az emberek és a robotok erősségeit kihasználja, miközben ellensúlyozza hátrányaikat (Seyitoğlu \& Ivanov, 2020a).

\section{A kutatás limitációi és további kutatási irányok} A jelenlegi kutatások túlnyomó része a turizmusra és a vendéglátásra fókuszál, mely korlátozott következtetéseket enged levonni a szolgáltató robotokkal kapcsolatban. Azonban ezek a kutatások kitérnek a turizmus-vendéglátásban tapasztalt fogyasztói élmény, veszélyelhárítás 
növekedésére és az ezáltal történő értékteremtés-növekedésre is (Seyitoğlu \& Ivanov, 2020b-c). Érdemes lenne további kutatásokat folytatni a többi iparágban is, ugyanis a Covid-19 hatása a turizmus-vendéglátás mellett erősen érintette a fent említett iparágakat is. Az automatizáció a robotizációval, illetve összességében a digitalizáció számos problémára válaszként szolgálhatott a fentebb említett iparágakban, ahogy erre néhány példát említettünk cikkünkben. Több hazai kutatás is kitért már a robotok megjelenésére, többek között a szolgáltató központok kapcsán (Marciniak, Móricz \& Baksa, 2020), illetve a kiskereskedelemben is tapasztalható térnyerésük (Agárdi, 2018). Azonban ezen kutatások nem a szolgáltató robotokat állították a fókuszba, hanem a digitalizáció hatására történő megjelenésükkel foglalkoztak.

Nem szabad figyelmen kívül hagyni azonban a nehézségeket és kihívásokat, amelyeket a szolgáltató robotok elterjedése hoz magával a stratégiatervezés, a humánerőforrás-menedzsment, és az ellátási láncok oldaláról, így ezek kutatására mindenképpen szükség van a jövőben.

Izgalmas kérdések lehetnek, hogy amennyiben mind az ipar, mind a szolgáltatások területein elterjednek a szolgáltató robotok, milyen iparági sajátosságok jelenhetnek meg alkalmazásukat illetően, továbbá, hogy milyen szerepekben jelenhetnek meg a vállalatok értékláncaiban, és az értékláncok támogató tevékenységeinek milyen mértékü fejlesztése lesz kívánatos a robotok sikeres implementációjához.

\section{Felhasznált irodalom}

Agárdi, I. (2018). A digitalizáció mint a kiskereskedelmi tevékenységet integráló tényező. Vezetéstudomány, 49(12), 50-57.

https://doi.org/10.14267/veztud.2018.12.06

Belanche, D., Casaló, L. V., \& Flavián, C. (2020). Frontline robots in tourism and hospitality: Service enhancement or cost reduction? Electronic Markets, 31, 477-492. https://doi.org/10.1007/s12525-020-00432-5

Belanche, D., Casaló, L. V., Flavián, C., \& Schepers, J. (2020a). Service robot implementation: A theoretical framework and research agenda. The Service Industries Journal, 40(3-4), 203-225. https://doi.org/10.1080/02642069.2019.1672666

Belanche, D., Casaló, L. V., Flavián, C., \& Schepers, J. (2020b). Robots or frontline employees? Exploring customers' attributions of responsibility and stability after service failure or success. Journal of Service Management, 31(2), 267-289.

https://doi.org/10.1108/JOSM-05-2019-0156

Calderone L (2019) What are service robots? RoboticsTomorrow. https ://www.roboticstomorrow.com/article/2019/02/what-are-service-robot s/13161

Castillo, D., Canhoto, A. I., \& Said, E. (2020). The dark side of AI-powered service interactions: Exploring the process of co-destruction from the customer perspective. The Service Industries Journal, 41(13-14), 1-26. https://doi.org/10.1080/02642069.2020.1787993
Cha, S. S. (2020). Customers' intention to use robot-serviced restaurants in Korea: Relationship of coolness and MCI factors. International Journal of Contemporary Hospitality Management, 32(9), 2947-2968.

https://doi.org/10.1108/IJCHM-01-2020-0046

Chiang, A.-H., \& Trimi, S. (2020). Impacts of service robots on service quality. Service Business, 14(3), 439459.

https://doi.org/10.1007/s11628-020-00423-8

Choi, Y., Oh, M. (Moon), Choi, M., \& Kim, S. (Sam). (2020). Exploring the influence of culture on tourist experiences with robots in service delivery environment. Current Issues in Tourism, 24(5), 1-17.

https://doi.org/10.1080/13683500.2020.1735318

Darling, K. (2012). Extending Legal Protection to Social Robots: The Effects of Anthropomorphism, Empathy, and Violent Behavior Towards Robotic Objects. We Robot Conference 2012, University of Miami. http://dx.doi.org/10.2139/ssrn.2044797

Demeter, K., \& Losonci, D. (2020). Business and technological perspectives of Industry 4.0 A framework for thinking with case illustration. Vezetéstudomány, 51(5), 2-14.

https://doi.org/10.14267/veztud.2020.05.01

Estolatan, E., Geuna, A., Guerzoni, M., \& Massimiliano, N. (2018). Mapping the Evolution of the Robotics Industry: A cross country comparison. Department of Economics and Statistics Cognetti de Martiis. Working Papers 201812. University of Turin. https:// munkschool.utoronto.ca/ipl/files/2018/07/robots-final-Jul11.pdf

Fink, A. (2005). Conducting Research Literature Reviews: From the Internet to Paper. Thousand Oaks: SAGE.

Foster, M. (2018). Aging Japan: Robots may have role in future of elder care. Retrieved from https://www.reuters.com/article/us-japan-ageing-robots-widerimage/ agingjapan- robots-may-have-role-in-future-of-eldercare-idUSKBN1H33AB

Frey, C. B., \& Osborne, M. A. (2017). The future of employment: How susceptible are jobs to computerisation? Technological Forecasting and Social Change, 114, 254-280.

https://doi.org/10.1016/j.techfore.2016.08.019

Gallagher, K. E., Kadokura, E., Eckert, L. O., Miyake, S., Mounier-Jack, S., Aldea, M., ... \& Watson-Jones, D. (2016). Factors influencing completion of multi-dose vaccine schedules in adolescents: a systematic review. BMC Public Health, 16(1), 1-17.

https://doi.org/10.1186/s12889-016-2845-z

Gartner. (2017). Hype Cycle for Emerging Technologies. https://www.gartner.com/en/documents/3885468/ hype-cycle-for-emerging-technologies-2018

Haidegger, T., Barreto, M., Gonçalves, P., Habib, M., Ragavan, S., Li, H., Vaccarella, A., Perrone, R., \& Prestes, E. (2013). Applied ontologies and standards for service robots. Robotics and Autonomous Systems, 61(11), 1215-1223, https://doi.org/10.1016/j.robot.2013.05.008 
Halaweh, M. (2013). Emerging Technology: What is it? Journal of Technology Management Innovation, 8(3), (online). https://doi.org/10.4067/S0718-27242013000400010

Ho, T. H., Tojib, D., \& Tsarenko, Y. (2020). Human staff vs. service robot vs. fellow customer: Does it matter who helps your customer following a service failure incident? International Journal of Hospitality Management, 87, 102501. https://doi.org/10.1016/j.ijhm.2020.102501. Industrial Robots.

International Federation of Robotics (2016). Industrial Robots. https://ifr.org/img/office/Industrial_Robots_2016_Chapter_1_2.pdf 2019.02.28

International Federation of Robotics (2016). Service robot, provisional definition of service robots. https ://www. ifr.org/servi ce-robot s/

Ivanov, S.H., Webster, C. and Berezina, K. (2017). Adoption of robots and service automation by tourism and hospitality companies. Revista Turismo and Desenvolvimento, 27(28), 1501-1517. https://papers.ssrn.com/ sol3/papers.cfm?abstract id $=2964308$

Karabegović, I., Husak, E., \& Predrag, D. (2019). The Role of Service Robots in Industry 4.0-- Smart Automation of Transport. Industry 4.0, 4(6), 290-292, https:// stumejournals.com/journals/14/2019/6/290

Kerr, K. (2014). Postmodern Cowboy: C. Wright Mills and a New 21st-Century Sociology, London: Routledge.

Kikuchi, T. (2018). Robot staff make Japan's Henn na Hotels quirky and efficient. https://asia.nikkei.com/ Business/Robot-staff-make-Japan-s-Hennna-Hotelsquirky-and-efficien

Kuo, C.-M., Chen, L.-C., \& Tseng, C.-Y. (2017). Investigating an innovative service with hospitality robots. International Journal of Contemporary Hospitality Management, 29(5), 1305-1321.

https://doi.org/10.1108/IJCHM-08-2015-0414

Lechevalier S, Nishimura J, Storz C (2014) Diversity in patterns of industry evolution: how an intrapreneurial regime contributed to the emergence of the service robot industry. Research Policy 43(10):1716-1729 https://doi.org/10.1016/j.respol.2014.07.012

Lee, S. \& Lee, D. (2019). Untact: a new customer service strategy in the digital age. Service Business, 13(1), 1-22, https://link.springer.com/article/10.1007/s11628019-00408-2

Liao, Y., Deschamps, F., Loures, E. D. F. R., \& Ramos, L. F. P. (2017). Past, present and future of Industry 4.0-a systematic literature review and research agenda proposal. International Journal of Production Research, 55(12), 3609-3629. https://doi.org/10.1080/00207543.2017.1308576

Losonci, D., Takács, O., \& Demeter, K. (2019). Az Ipar 4.0 hatásainak nyomában - a magyarországi járműipar elemzése. Közgazdasági Szemle, 66(2), 185-218. http://dx.doi.org/10.18414/KSZ.2019.2.185

Lu, L., Cai, R., \& Gursoy, D. (2019). Developing and validating a service robot integration willingness scale. International Journal of Hospitality Management, 80, 36-51. https://doi.org/10.1016/j.ijhm.2019.01.005
Lu, V. N., Wirtz, J., Kunz, W., Paluch, S., Gruber, T., Martins, A., \& Patterson, P. (2020). Service robots, customers, and service employees: what can we learn from the academic literature and where are the gaps? Journal of Service Theory and Practice, 30(3), 361-391. https://doi.org/10.1108/JSTP-04-2019-0088

Marciniak, R., Móricz, P., \& Baksa, M. (2020). Lépések a kognitív automatizáció felé. Vezetéstudomány, 51(6), 42-55. https://doi.org/10.14267/VEZTUD.2020.06.05

Matarić M (2017) Socially assistive robotics: human augmentation versus automation. Science Robotics, 2(4), 1-2. https://www.science.org/doi/10.1126/scirobotics. aam5410

Miller, D. (2016). Natural Language: The User Interface for the Fourth Industrial Revolution. San Francisco, CA: Opus Research Report. https://www.softwareag. com/corporate/images/Natural $\% 20$ Language $\% 20$ The\%20User\%20Interface_tcm389-170321.pdf

Okoli, C., \& Schabram, K. (2010). A guide to conducting a systematic literature review of information systems research. http://dx.doi.org/10.2139/ssrn.1954824

Paluch, S., Wirtz, J., \& Kunz, W. H. (2019). Service Robots and the Future of Service. In Bruhn, M., Burmann, C., \& Kirchgeorg, M. (Eds.), Marketing Weiterdenken - Zukunftspfade für eine marktorientierte Unternehmensführung (pp.423-435). Cham: Springer Gabler.

Reis, J., Melão, N., Salvadorinho, J., Soares, B., \& Rosete, A. (2020). Service robots in the hospitality industry: The case of Henn-na hotel, Japan. Technology in Society, 63, 174-186. https://doi.org/10.1016/j.techsoc.2020.101423

Reiser, U., Connette, C., Fischer, J., Kubacki, J., Bubeck, A., Weisshardt, F., Jacobs, T., Parlitz, C., Hagele, M., \& Verl, A. (2009). Care-O-bot ${ }^{\circledR} 3$-creating a product vision for service robot applications by integrating design and technology. In IEEE/RSJ International Conference on Intelligent Robots and Systems in St. Louis, MO, 2009 (pp. 1992-1998). New Jersey: IEEE. https://doi.org/10.1109/IROS.2009.5354526

Rosete, A., Soares, B., Salvadorinho, J., Reis, J., \& Amorim, M. (2020). Service Robots in the Hospitality Industry: An Exploratory Literature Review. In Nóvoa, H., Drăgoicea, M., \& Kühl, N. (Eds.), Exploring Service Science. IESS 2020. Lecture Notes in Business Information Processing, vol 377. (pp. 174-186). Cham: Springer. https://doi.org/10.1007/978-3-030-38724-2_13

Rotolo, D., Hicks, D., \& Martin, B. (2015). What is an Emerging Technology? Science Policy Research Unit 2015-06. Brighton: University of Sussex. https://www. sussex.ac.uk/webteam/gateway/file.php?name=201506-swps-rotolohicksmartin.pdf\&site $=25$

Schneider, C. (2017). 10 reasons why AI-powered, automated customer service is the future. https://www.ibm. com/blogs/watson/2017/10/10-reasons-aipowered-automated-customerservice-future/ 
Schwab, K. (2015). The Fourth Industrial Revolution: What It Means and How to Respond. Foreign Affairs. https:/www.foreignaffairs.com/articles/2015-12-12/ fourth-industrial-revolution

Seyitoğlu, F., \& Ivanov, S. (2020a). A conceptual framework of the service delivery system design for hospitality firms in the (post-)viral world: The role of service robots. International Journal of Hospitality Management, 91(July). https://doi.org/10.1016/j.ijhm.2020.102661

Seyitoğlu, F., \& Ivanov, S. (2020b). Service robots as a tool for physical distancing in tourism. Current Issues in Tourism, 24(12), 1-4. https://doi.org/10.1080/13683500.2020.1774518

Seyitoğlu, F., \& Ivanov, S. (2020c). Understanding the robotic restaurant experience: a multiple case study. Journal of Tourism Futures, Vol. ahead-of-print No. ahead-of-print. https://doi.org/10.1108/JTF-04-2020-0070

Shin, H. H., \& Jeong, M. (2020). Guests' perceptions of robot concierge and their adoption intentions. International Journal of Contemporary Hospitality Management, 32(8), 2613-2633. https://doi.org/10.1108/IJCHM-09-2019-0798

Singh, B., \& Sellappan, N. (2013). Evolution of Industrial Robots and their Applications. International Journal of Emerging Technology and Advanced Engineering, 3(5), 763-768. https://citeseerx.ist.psu.edu/viewdoc/ download?doi=10.1.1.413.8024\&rep=rep1\&type $=$ pdf

Struijk, B. (2011). Robots in human societies and industry. Technology, 10(1), 183-195.

Tung, V. W. S., \& Law, R. (2017). The potential for tourism and hospitality experience research in human-robot interactions. International Journal of Contemporary Hospitality Management, 29(10), 2498-2513. https://doi.org/10.1108/IJCHM-09-2016-0520

Tussyadiah, I. (2020). A review of research into automation in tourism: Launching the Annals of Tourism Research Curated Collection on Artificial Intelligence and Robotics in Tourism. Annals of Tourism Research, 81(February), 102883.

https://doi.org/10.1016/j.annals.2020.102883

Tussyadiah, I. P., Zach, F. J., \& Wang, J. (2020). Do travelers trust intelligent service robots? Annals of Tourism Research, 81(June), 102886. https://doi.org/10.1016/j.annals.2020.102886

van Pinxteren, M. M. E., Wetzels, R. W. H., Rüger, J., Pluymaekers, M., \& Wetzels, M. (2019). Trust in humanoid robots: implications for services marketing. Journal of Services Marketing, 33(4), 507-518. https://doi.org/10.1108/JSM-01-2018-0045

Walsh, N. (2018). Next time you order room service, it may come by a robot. The New York Times. https://www. nytimes.com/2018/01/29/travel/the nexttime- you-order-room-service-it-may-come-by-robot.html

Wirtz, J. (2020). Organizational Ambidexterity: Cost-Effective Service Excellence, Service Robots, and Artificial Intelligence. Organizational Dynamics, 49, 1-9. https://doi.org/10.1016/j.orgdyn.2019.04.005

Wirtz, J., Patterson, P. G., Kunz, W. H., Gruber, T., Lu, V. N., Paluch, S., \& Martins, A. (2018). Brave new world: service robots in the frontline. Journal of Service Management, 29(5), 907-931. https://doi.org/10.1108/JOSM-04-2018-0119

World Economic Forum (2018). Readiness for the Future of Production. http://www3.weforum.org/docs/FOP Readiness_Report_2018.pdf

Xu, M., David, J. M., \& Kim, S. H. (2018). The fourth industrial revolution: opportunities and challenges. International Journal of Financial Research, 9(2), 90-95. https://doi.org/10.5430/ijfr.v9n2p90

Xu, S., Stienmetz, J., \& Ashton, M. (2020). How will service robots redefine leadership in hotel management? A Delphi approach. International Journal of Contemporary Hospitality Management, 32(6), 2217-2237.

https://doi.org/10.1108/IJCHM-05-2019-0505

Yanhui, L. I. U., Guoqing, Z. H. U., Zhengqin, L. I. U., Xinyi, H. U., \& Jiang, R. (2020). Tactile design of manipulator fingers based on fingertip/textile friction-induced vibration stimulations. Industria Textila, 71(1), $28-32$.

https://doi.org/10.35530/IT.071.01.1354

Zhong, L., Zhang, X., Rong, J., Chan, H. K., Xiao, J., \& Kong, H. (2020). Construction and empirical research on acceptance model of service robots applied in hotel industry. Industrial Management and Data Systems, 121(6), 1325-1352

https://doi.org/10.1108/IMDS-11-2019-0603 